\title{
Etnomatematika Pada Kebudayaan Suku Dayak Bentian Dalam Menumbuhkembangkan Literasi Matematis
}

\author{
Nurdin Arifin $^{1 *}$, Eudia Fortuna ${ }^{2}$ \\ ${ }^{*}$ Universitas Widya Gama Mahakam Samarinda \\ ${ }^{2}$ Universitas Widya Gama Mahakam Samarinda \\ "nurdin.arifin91@gmail.com
}

\begin{abstract}
Mathematical concepts are always useful in everyday life to solve problems at hand. Learning mathematics that is associated with the surrounding (contextual) circumstances, especially in the culture of an area, is expected to be able to improve the ability of students in learning. Learning mathematics which is associated with the culture of an area is called ethnomathematics. Moreover, the government is currently promoting literacy. Literacy in mathematics is called mathematical literacy/mathematical literacy is the knowledge to know and apply basic mathematics every day such as to communicate both orally and in writing, to reason, and to solve problems. This service is carried out through a zoom meeting application that is given to 6th semester students, as a preparation effort before students carry out the Introduction to Learning Environment (PLP) at school. This service method uses the ADDIE (Analyze, Design, Develop, Implementation, and Evaluation) model. In the results of this service, a discussion was held on the ethnomathematics of the Bentian Dayak tribe in relation to learning mathematics and participants were able to make mathematical literacy questions. In the end, participants will be able to apply ethnomathematics and mathematical literacy in learning
\end{abstract}

Keywords: Ethnomathematics, Bentian Dayak Tribe, Mathematical Literacy, Elementary School

\begin{abstract}
Abstrak
Konsep matematika selalu berguna dalam kehidupan sehari-hari untuk menyelesaikan permasalahan yang dihadapi. Pembelajaran matematika yang dikaitkan dengan keadaan sekitar (kontekstual) khusunya pada budaya suatu daerah diharapkan mampu meningkatkan kemampuan peserta didik dalam pembelajaran. Pembelajaran matematika yang dimana dikaitkan dengan budaya dari suatu daerah hal ini disebut etnomatematika. Apalagi, saat ini pemerintah sedang menggaungkan literasi. Literasi dalam matematika disebut dengan literasi matematis/literasi matematika merupakan pengetahuan untuk mengetahui dan menerapkan matematika dasar setiap hari seperti untuk mengomunikasikan baik secara lisan ataupun tulisan, menalar, dan memecahkan masalah. Pengabdian ini dilaksanaakan melalui aplikasi zoom meeting yang diberikan kepada mahasiswa semeseter 6 , sebagai upaya persiapan sebelum para mahasiswa melaksanakan Pengenalan Lingkungan Pembelajaran (PLP) di sekolah. Metode pengabdian ini menggunakan model ADDIE (Analyze, Design, Develop, Implementation, and Evaluation). Pada hasil pengabdian ini dilakukan diskusi mengenai etnomatematika suku dayak bentian dalam kaitannya dalam pembelajaran matematika dan peserta mampu membuatan soal literasi matematika. Pada akhirnya, nantinya peserta mampu menerapkan etnomatematika dan literasi matematika pada pembelajaran.
\end{abstract}

Kata kunci: Etnomatematika, Dayak Bentian, Literasi Matematika, Sekolah Dasar

\section{PENDAHULUAN}

Matematika merupakan ilmu yang membahas mengenai kuantitas, struktur, ruang, dan perubahan (Kurniawan, 2020). Matematika merupakan induk dari berbagai ilmu pengetahuan lain dan memiliki peran untuk membantu perkembangan ilmu tersebut (Suherman, 2012). Konsep Matematika selalu digunakan dalam penyelesaian masalah di kehidupan sehari-hari. Seiring berjalannya waktu, upaya meningkatkan kualitas pendidikan dan pembelajaran matematika terus dilakukan dengan cara yang beragam, seperti dengan melakukan pelatihan/Workshop materi pembelajaran matematika, media pembelajaran matematika dan lain-lainnya. Selain itu, upaya meningkatkan kualitas pendidikan juga bergantung pada kemampuan guru dalam menguasai dan menyampaikan pembelajaran matematika kepada 
siswa dengan baik. Guru harus bisa memanfaatkan berbagai macam objek maupun media dalam pembelajaran. Hal itu dapat menjadi penunjang bagi siswa dalam memahami materi yang diajarkan.

Media yang dapat digunakan dalam pembelajaran matematika sangat beragam, contohnya seperti benda-benda sekitar, baik itu benda mati maupun hidup, termasuk adat dan budaya yang ada. Suku Dayak Bentian yang berada di Kampung Suakong, Kecamatan Bentian Besar, Kabupaten Kutai Barat, Provinsi Kalimantan Timur memiliki kebudayaannya yang beragam. Kebudayaan tersebut tidak lepas dari matematika. Menurut Bishop (Dominikus, 2019) matematika merupakan aktivitas manusia, konstruksi sosial budaya, fenomena budaya, matematika terkandung dalam budaya, terikat dengan budaya, dan memengaruhi budaya.

Wahyuni et al (Hardiarti, 2017) menyatakan bahwa salah satu yang dapat menjembatani budaya dan matematika adalah etnomatematika. Etnomatematika terdiri dari kata etno (etnis/budaya) dan matematika sehingga dapat diartikan bahwa etnomatematika merupakan matematika dalam budaya. Dimpudus \& Ding (2019) menyatakan bahwa Etnomatematika mengacu pada konsep-konsep matematika yang tertanam dalam berbagai praktek budaya serta mengakui bahwa semua budaya dan semua orang mengembangkan metode unik untuk memahami dan mengubah realitas komunitas budaya.

Lebih lanjut Francois mengatakan etnomatematika menjadi jalan mengajar matematika di mana keragaman budaya matematika sehari-hari murid praktik seni diperhitungkan. D'Ambrosio menyebut Ethnomathematics sebagai seni atau teknik untuk menjelaskan, mengetahui atau memahami caranya seseorang atau kelompok menghasilkan pengetahuan matematika,yang mana digunakan untuk mengorganisis, mentrasmisikan pembelajaran matematika dengan budaya. Hal ini menunjukkan bahwa pembelajaran matematika dengan mengaitkan budaya yang mana nantinya siswa sebagai peserta didik mampu melakukan pembelajaran bukan hanya di kelas tetapi dalam kehidupan sehari-hari khususnya dalam budaya sekitar.

Adapun tujuan dari kegiatan eksplorasi dan kajian mengenai etnomatematika adalah untuk dapat lebih memahami lagi keterkaitan antara matematika dan budaya, agar persepsi siswa maupun masyarakat mengenai matematika menjadi lebih tepat. Selain itu penerapan pembelajaran matematika dapat disesuaikan dengan konteks budaya lokal sehingga pembelajaran matematika lebih mudah dipahami dan budaya-budaya lokal tidak dilupakan oleh siswa setempat.

Hasil TIMSS (Trends in Internastional Mathematics and Science Study) pada tahun 2003, Indonesia berada di peringkat ke-35 dari 46 negara peserta dengan skor rata-rata 411, sedangkan untuk skor rata-rata internasional 467. Pada hasil studi TIMSS 2007, Indonesia berada di peringkat ke-36 dari 49 negara peserta dengan skor rata-rata 397, sedangkan skor rata-rata internasional 500. Serta hasil studi TIMSS 2011, Indonesia berada diperingkat ke-38 dari 42 negara peserta dengan skor rata-rata 386, sedangkan skor rata-rata internasional 500 (Arifin \& Abadi, 2018). Sedangkan hasil penilaian yang terakhir yakni pada tahun 2015 hasil TIMSS bahwa Indonesia berada di peringkat 44 dari 49 negara peserta dengan skor rata-rata (Mullis et al, 2015: 15)

Pada Tes PISA yang terbaru pada tahun 2018 yang dilakukan OECD yang diperoleh dari hasil kemampuan membaca, matematika, dan IPA hahwa, rata-rata skor PISA negara Indonesia yakni 371 untuk aspek membaca, 379 untuk matematika, dan 396 untuk IPA dimana Indonesia berada diperingkat 36 dari 41 peserta yang ternyata masih berada di bawah rata-rata internasional dari aspek membaca yakni 487, matematika yakni 489, dan IPA yakni 489. (OECD, 2019: 18).

Universitas Widya Gama Mahakam Samarinda perguruan tinggi di Samarinda yang dimana memiliki Program studi Pendidikan Guru Sekolah Dasar (PGSD) yang melaksanakan 
kegiatan belajar mengajar dalam lingkup menyiapkan pendidik sekolah dasar. Selain itu juga berikhtiar memberikan kontribusi terhadap masyarakat khususnya pada mata pelajaran matematika sebagai usaha pengabdian kepada masyarakat agar peserta didik di kota Samarinda dapat lebih memahami dan meningkatkan kemampuan literasi, numerisasi, dan sains.

Meningkatkan literasi merupakan tantangan di Indonesia bahkan seluruh dunia. Masyarakat saat ini membutuhkan peningkatan kemampuan untuk menangani informasi dan berinteraksi secara kolaboratif ditengah lajunya inforasi yang saat ini semkin mudah di akses. Literasi matematika merupakan hal yang penting didapatkan oleh peserta didik. Sumirattana, Makanong, Thipkong (2016) mengungkapkan bahwa literasi matematika merupakan hal yang penting serta merupakan kemampuan yang fundamental, sehingga dalam mengajarkan matematika di sekolah ketika peserta didik memiliki literasi matematika maka akan mampu menerapkan pengetahuan matematikanya dalam kehidupan sehari-hari. Karena dalam kehidupan sehari-hari peserta didik harus mampu memecahkan masalah dengan pengetahuan dan keterampilan yang dimilikinya (Yavuz \& Erbay, 2015). Penerapan literasi matematis di sekolah memainkan peranan yang penting dalam bagian kesuksesan akademik serta sebagai kemampuan untuk menerapkan informasi cetak ataupun tulisan untuk berfungsi dalam masyarakat yang dimana untuk mencapai tujuan seseorang, dan untuk mengembangkan pengetahuan dan potensi seseorang. (Clem et al., 2021)

Literasi matematis yang digaungkan oleh PISA melakukan pendefinisian ulang. PISA 2012 mendefiniskan literasi matematis merupakan kemampuan siswa untuk menggunakan matematika dalam memecahkan masalah di kehidupan nyata. Kemampuan literasi ini mencakup penalaran matematis serta penggunaan konsep, prosedur, dan fakta matematis untuk memprediksi fenomena di sekitar siswa. Pada tahun 2018 PISA membuat kerangka kerja PISA 2021 yang mana kemampuan literasi matematis merupakan kemampuan individu untuk menyadari keadaan matematis, meformulasikan, menerapkan dan memecahkan masalah dalam kehidupan sehari-hari (nyata) dengan menggunakan konsep-konsep matematis, prosedur dan fakta (OECD, 2018). Upaya meningkatkan literasi matematika siswa, siswa sejak sekolah dasar harus disuguhkan dengan kehidupan nyata masalah dan masalah interpretasi terbuka dan memungkinkan mereka untuk mendekati masalah dengan perspektif kritis. Langkah lain yang dapat diambil dalam bidang ini adalah meningkatkan kualitas guru sekolah dasar, guru matematika dan guru sains dan teknologi, yang terlibat dalam matematika (Y1lmazer \& Masal, 2014).

Melalui pelatihan etnomatematika pada kebudayaan suku dayak bentian dalam menumbuhkembangkan literasi matematis, yang mana mayoritas mahasiswa Universitas Widya Gama Mahakam Samarinda merupakan suku dayak, mampu menerapkan kebudayaan suku dayak lainnya nantinya dalam pembelajaran dan mampu membuat soal literasi matematika dalam pembelajaran. Selain itu melalui pembelajaran berbasis etnomatematika diharapkan dapat meningkatkan kecintaan mahasiswa dan masyarakat terhadap budaya yang mereka miliki dan sebagai usaha untuk meningkatkan kemampuan literasi bagi calon guru yang nantinya mampu diterpkan di sekolah kepada peserta didik.

\section{METODE PELAKSANAAN}

Sintaks pelaksanaan kegiatan pengabdian kepada masyarakat ini menggunakan model pengembangan yang digunakan dalam penelitian ini mengacu pada pengembangan metode ADDIE. Menurut Branch (2009: 2) bahwa,

ADDIE is an acronym for Analyze, Design, Develop, Implement, and Evaluate. Creating products using an ADDIE process remains one of today's most effective tools. Because ADDIE is merely a process that serves as a guiding framework for complex 
situations, it is appropriate for developing educational products and other learning resources.

Prosedur ADDIE terdiri dari lima tahap yaitu: analysis (analisis), design (perancangan), development (pengembangan), implementation (implementasi), dan evaluation (evaluasi).

Berdasarkan model pengembangan ADDIE di atas, pada tahap analysis memuat analisis kebutuhan, analisis peserta, dan analisis materi. Tahap design mencakup merancang program pelatihan etnomatematika dan penyusunan instrumen tes literasi matematis. Tahap development memuat bentuk materi pelatihan, persiapan peralatan dalam pelatihan, dan pembuatan evaluasi pelatihan. Tahap implementation yakni melaksanakan pelatihan. Tahap terakhir evaluation yakni mengevaluasi hal yang terkait dengan pelatihan yang telah dilaksanakan. Prosedur pelatihan secara sistematis dijelaskan dengan gambar 1 sebagai berikut.

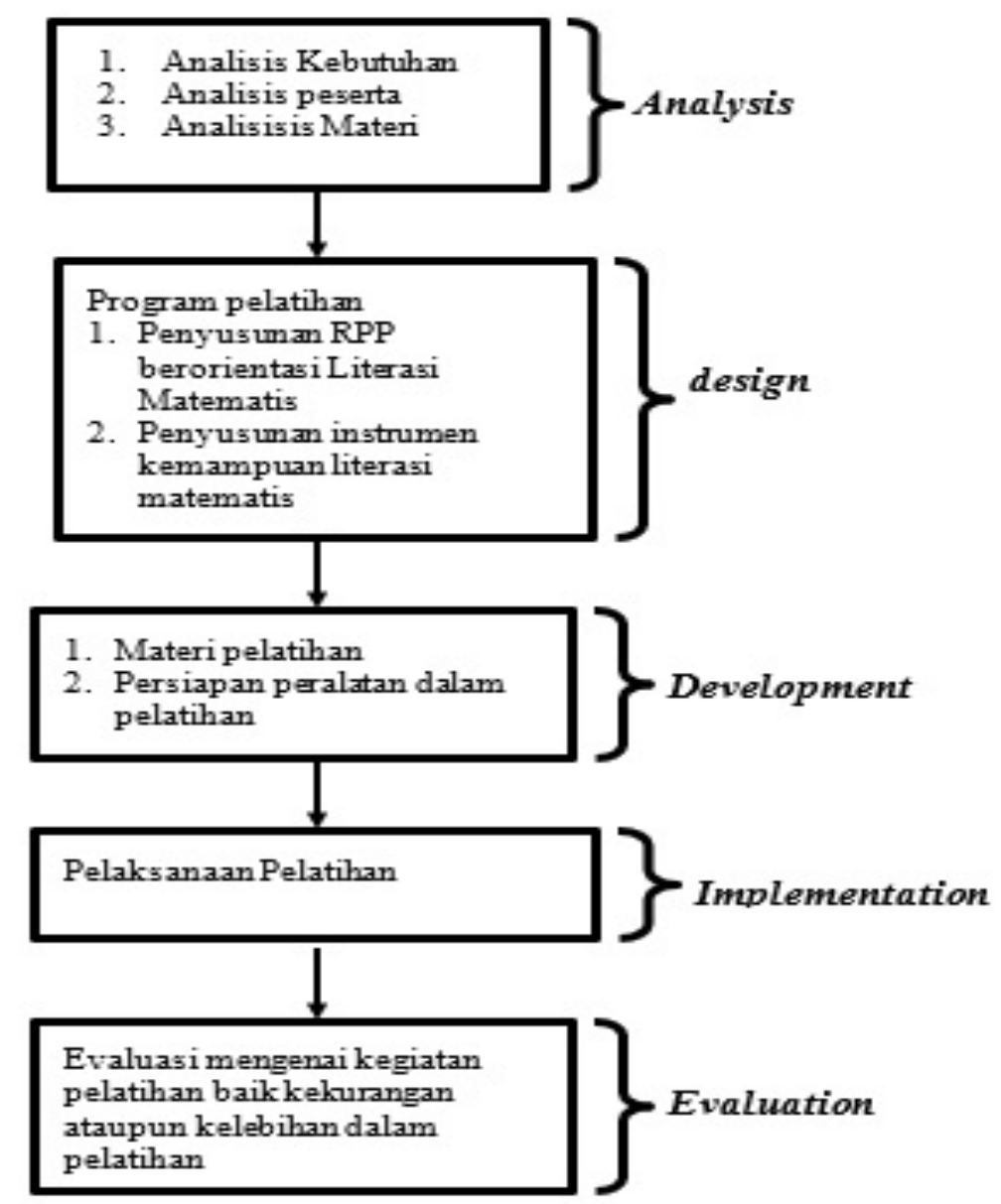

Gambar 1. Skema Prosedur Pelatihan dengan ADDIE

\section{Tahap Analisis (Analysis)}

Tahap analisis merupakan tahap pra-perencanaan pelatihan. Adapun tahapan ini dapat dijelaskan sebagai berikut.

a. Analisis Kebutuhan

Analisis kebutuhan dilakukan untuk mengetahui masalah dasar yang dihadapi dalam pembelajaran matematika di sekolah dasar yang dimana masih kurangnya para guru mengaitkan budaya dan matematika. Serta masih rendahnya literasi matematika peserta didik 
sehingga perlunya peran mahasiswa sebagai calon guru yang nantinya dapat mengajarkan matematika dengan mengaitkan budaya.

b. Analisis Peserta

Analisis peserta dengan menelaah karakteristik peserta pelatihan. Peserta pelatihan akan memperoleh pelatihan penyusunan instrumen tes literasi matematis.

c. Analisis Materi

Kegiatan yang dilakukan pada tahap ini adalah menganalisis materi matematika yang disajaikan kepada peserta yakni mahasiswa berdasarkan alat-alat serta rumah adat dari dayak Bentian.

\section{Tahap Perancangan (Design)}

Tahap perancangan bertujuan untuk mempersiapkan hal-hal yang diperlukan dalam pelatihan. Hal yang disusun dalam tahap perancangan, yaitu materi etnomatematika dan soal kemampuan literasi matematis yang diberikan.

\section{Tahap Pengembangan (Development)}

Tahap ini dilakukan pengembangan produk pelatihan yakni materi yang akan di sampaikan berkaitan dengan etnomatematika dan literasi matematis.

\section{Tahap Implementasi (Implementation)}

Tahap implementasi yakni pelaksanaan pemberian informasi etnomatematika suku Dayak Bentian dan literasi matematis.

\section{Tahap Evaluasi (Evaluation)}

Tahap evaluasi, peneliti mengevaluasi hal yang terkait dengan pelatihan yang dilaksanakan.

\section{HASIL DAN PEMBAHASAN}

Kegiatan pengabdian kepada masyarakat ini diikuti oleh mahasiswa PGSD Universitas Widya Gama Mahakam Samarinda. Kegiatan ini dilakukan scara daring dengan menggunakan zoom meeting. Kegiatan ini dilaksanakan pada 10 Juni 2021 dari pukul 09.00-12.30.

Pada awal pelaksanaan, pemateri menjelaskan mengenai etnomatematika. Kemudian memberikan contoh kerajinan dan rumah adat suku dayak Bentian yang memiliki keterkaitan dengan matematika. Adapun contohnya sebagai berikut.

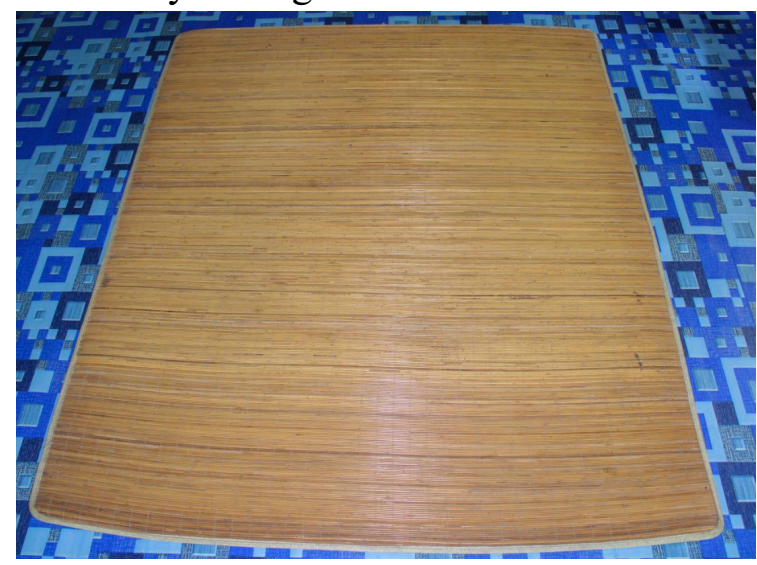

\section{Gambar 1. Apai Jaliq (Tikar Jaliq)}

Tikar Jaliq yang terbuat dari rotan yang dianyam ini mengandung unsur matematika yakni persegi atau segi empat, simetri lipat dan simetri putar. 


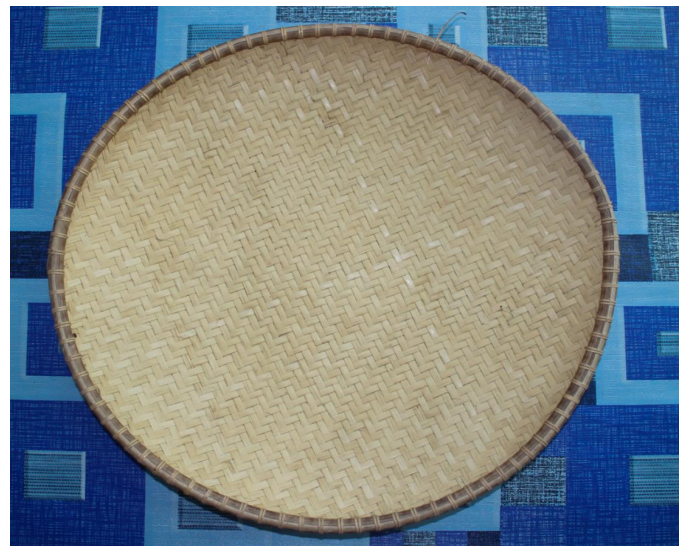

Gambar 2. Lewenq (Penampi Beras)

Penampi beras yang terbuat dari anyaman bambu dan rotan ini mengandung unsur matematika yakni lingkaran, simetri lipat, dan simetri putar.

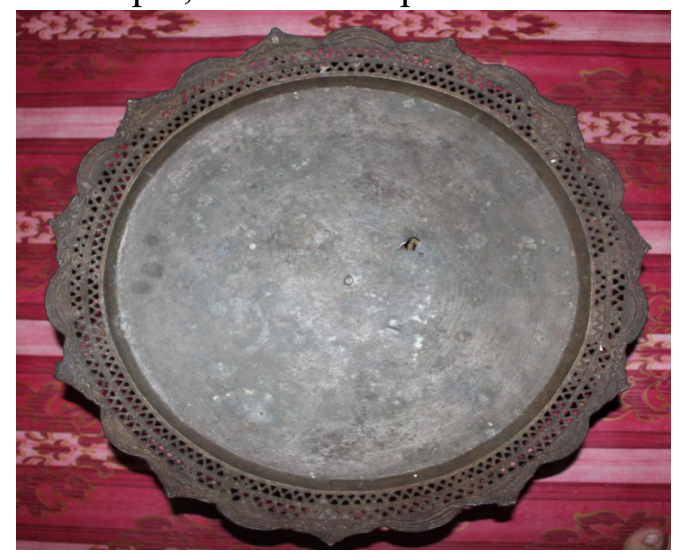

Gambar 3. Per (Baki/Tempat menaruh hidangan khas suku Dayak Bentian)

Baki yang terbuat dari bahan campuran logam yang ditempa ini mengandung unsur matematika yakni lingkaran, simetri lipat, dan simetri putar.

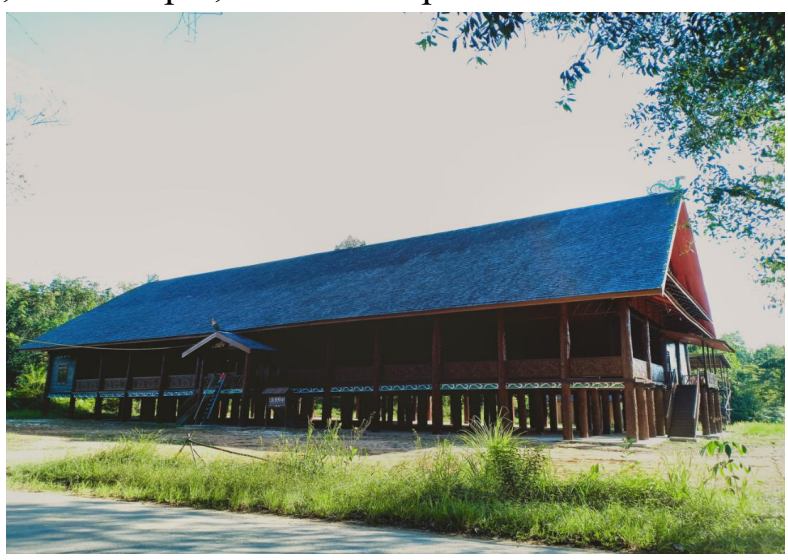

Gambar 4. Lou Bentian (tampak depan) 


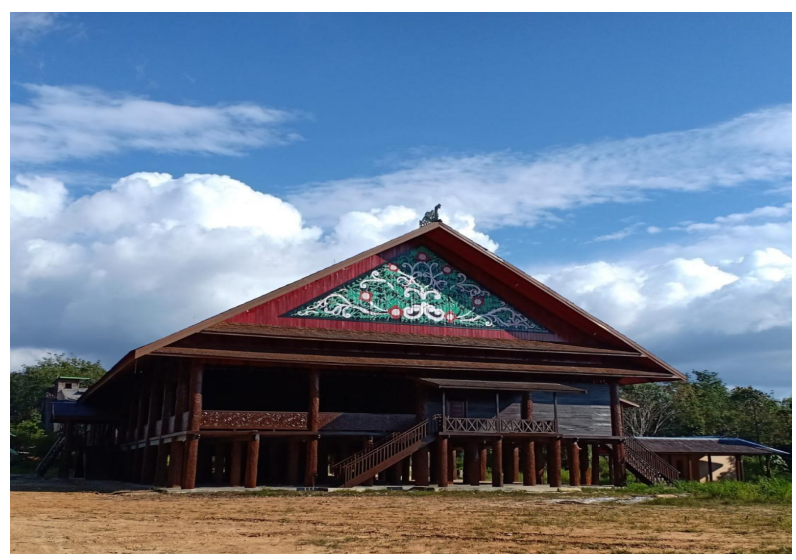

Gambar 5. Lou Bentian (tampak samping)

Rumah adat lamin khas suku dayak Bentian ini juga mengandung unsur-unsur matematika seperti segitiga, tabung, persegi, persegi panjang, dan lain-lainnya.

Pada sesi kedua, dilanjutkan mengenai literasi matematis yang dimana pemateri memberikan penjelasan literasi matematis. Literasisi matematis yang sesuai dengan PISA 2021. Selanjutnya pemateri memberikan contoh Lembar kegiatan Peserta Didik untuk menumbuhkembangkan literasi matematis. Adapun gambarnya disajikan sebagai berikut.

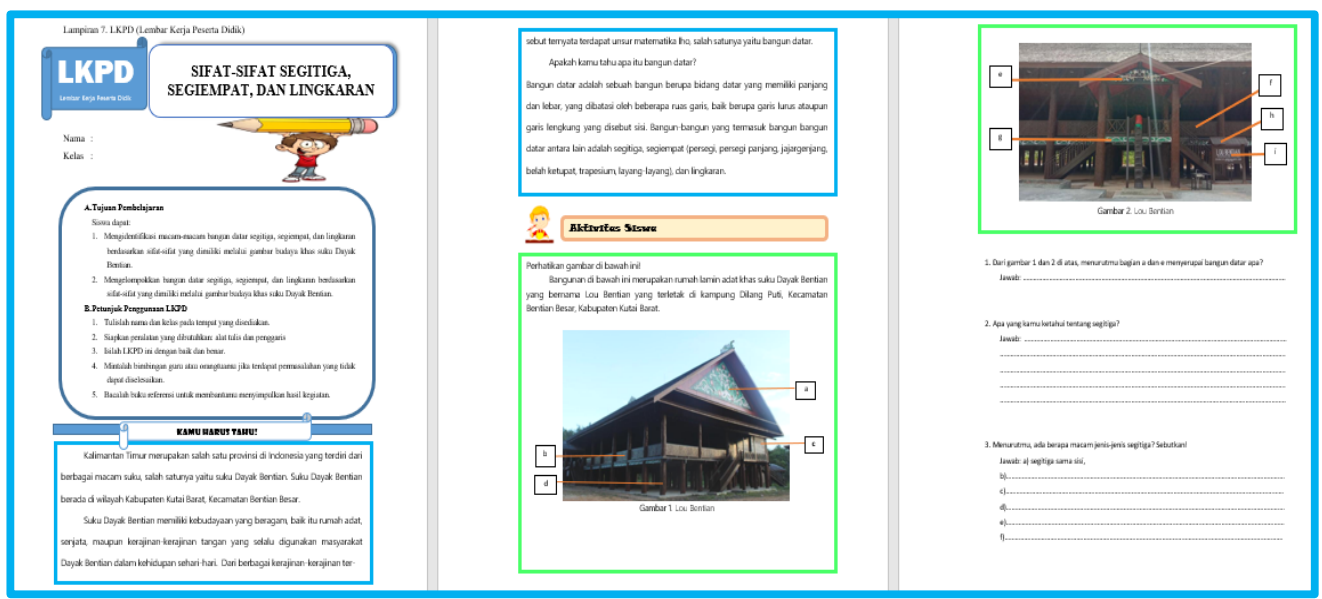

Gambar 6. Lembar Kegiatan Peserta Didik (LKPD) untuk Menumbuhkembangkan Literasi Matematis

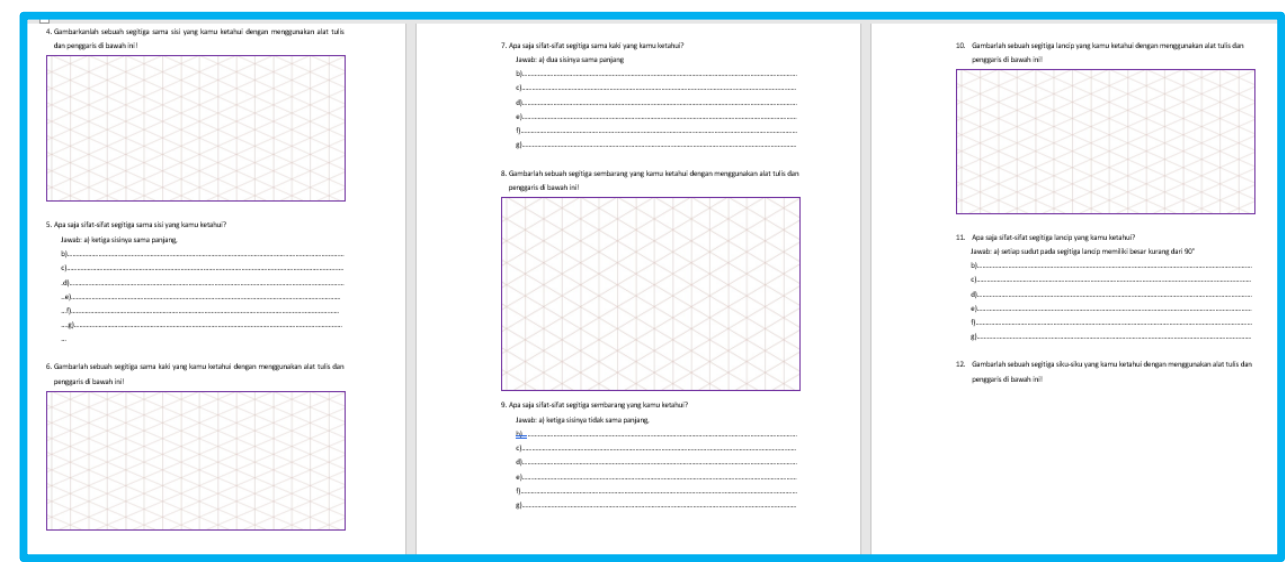

Gambar 7. Lembar Kegiatan Peserta Didik (LKPD) untuk Menumbuhkembangkan Literasi Matematis 


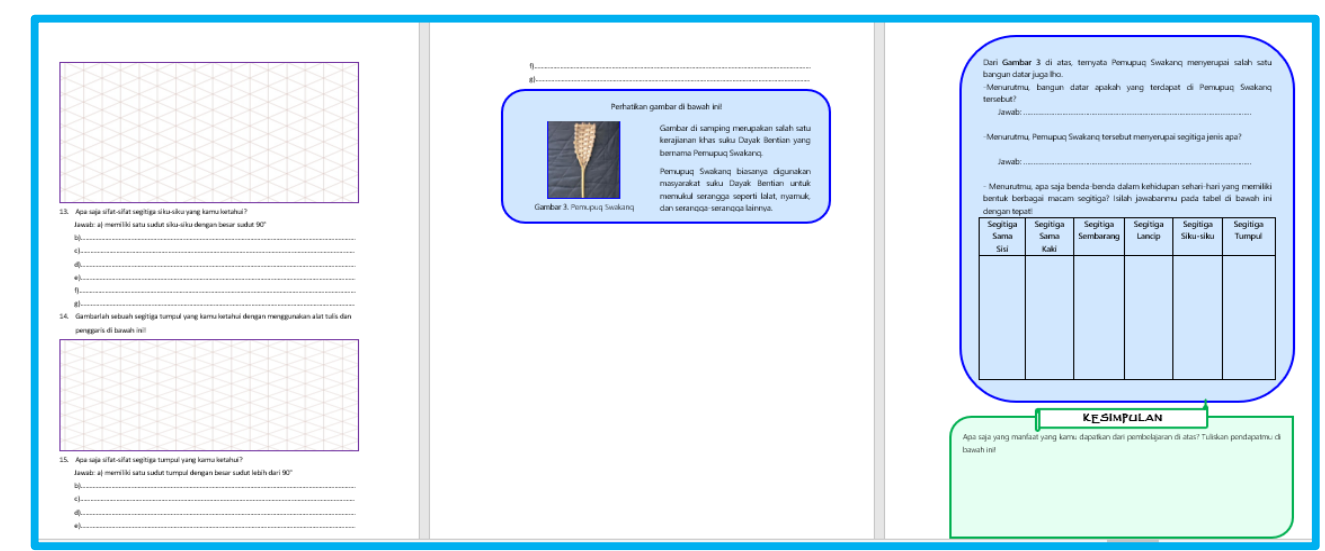

Gambar 8. Lembar Kegiatan Peserta Didik (LKPD) untuk Menumbuhkembangkan Literasi Matematis

Contoh LKPD yang dibuat memberikan informasi kepada mahasiswa bagaimana mengarahkan siswa nantinya untuk menumbuh kembangkan kemampuan literasi matematis dengan inti penalaran matematis dan pemecahan masalah. LKPD yang diberikan mengikuti konsep literasi matematis pada PISA. Adapun gambarnya sebagai berikut.

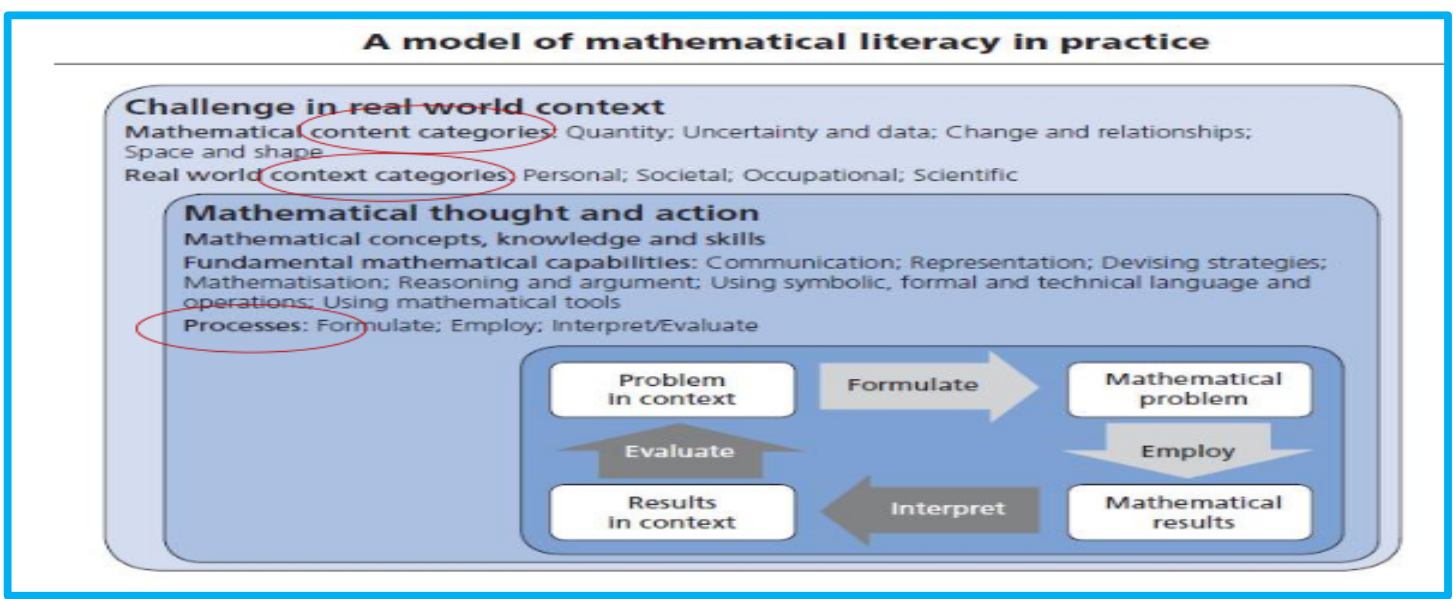

Gambar 9. Model Literasi Matematika berdasarkan OECD

Pada konsep literasi matematis yang diterapkan oleh PISA tersebut, pada persegi paling luar bahwa literasi matematis terjadi dalam konteks kehidupan sehari-hari yakni konteks konteks kehidupan sehari-hari dan konten matematika. Konteks kehidupan sehari-hari berkaitan denganasal muasal hadirnya permasalahan yang bisa dihadapi oleh individu, masyarakat, pengetahuan, ataupun pekerjaan. Konten matematika yang terdiri akan materi kuantitas, ketidakpastian dan data, perubahan dan keterkaitan, serta ruang dan bentuk.

Pada persegi bagian tengah bahwa individu harus mampu mengaplikasikan kemampuan berpikir dan melakuakan aktivitas matematis untuk memecahkan permasalahan dengan aktivitas yang dimiliki yakni komunikasi, representasi, mematematisasi, menalar dan berargumentasi, menggunakan strategi dalam menyelesaikan masalah, menggunakan operasi dan bahasa simbol, bahasa formal dan teknis, serta menggunakan alat-alat matematika.

Pada persegi bagian paling kecil dimana untuk memecahkan masalah, melakukan identifikasi konteks matematika yang sesuai dengan masalah kontekstual serta merumuskan matematisnya. Dalam hal ini menggunkan konsep, prosedur, fakta dan alat-alat matematika untuk diperolehnya hasil matematis yang melibatkan kemampuan penalaran, manipulasi, mengubah, dan melakukan operasi hitung. Kemudian, hasil matematis yang diinterpratsikan 
berupa hasil dalam konteks, mengikutsertakan kemampuan interprtasi, menerapkan dan melakukan evaluasi hasil yang diperoleh.

Pada sesi terakhir yakni sesi ketiga, dimana melakukan diskusi mengenai etnomatematika dan literasi matematis. Kemudian meminta para peserta untuk membuat soal yang berakitan dengan literasi matematis, serta meminta para peserta untuk memberikan respon mengenai pelatihan yang diberikan berkaitan dengan etnomatematika suku dayak Bentian dan literasi matematis. Respon peserta dalam mengikuti pelatihan ini mengatakan agar nantinya pelatihan seperti ini agar terus dilanjutkan, mampu memberikan informasi mengenai suku-suku dayak lainnya ataupun suku-suku yang berada di Kalimantan pada Umumnya. Agar nantinya sebagai upaya untuk para peserta semakin mengetahui tentang suku-suku asli kalimantan yang diharapkan mampu memberikan dampak positif dalam pembelajaran. Memberikan gambaran konteks matematika yang disampaikan berupa rumah adat (lamin) Lou Bentian, konten berkaitan dengan materi yakni bangun datar (geometri dan pengukuran) serta bilangan dan operasinya. Proses/kompetensi berupa melakukan membuat grafik, menganalisis, ataupun membedakan.

\section{KESIMPULAN}

Berdasarkan hasil kegiatan pengabdian masyarakat bahwa para peserta pelatihan telah memiliki pengetahuan mengenai etnomatematika secara umum dan khususnya etnomatematika suku dayak, memiliki kemampuan untuk membuat soal literasi matematis yang nantinya diharapkan dapat diterapkan pada saat mengajar di sekolah. Sebagai upaya untuk melestarikan budaya-budaya yang ada di Indonesia dengan menggunakan matematika.

\section{Ucapan terimakasih}

Penulis mengucapkan terima kasih kepada Universitas Widya Gama Mahakam Samarinda melalui LPPM yang telah memberi bantuan dana untuk kegiatan pengabdian masyarakat sehingga berjalan dengan lancar.

\section{DAFTAR PUSTAKA}

Arifin, N., \& Abadi, A. M. (2018). Pengembangan Perangkat Pembelajaran Matematika dengan Discovery Learning Berorientasikan Kemampuan Penalaran dan Komunikasi Matematis. Jurnal Pendas Mahakam, 3(2), 125-138.

Branch, R. M. (2009). Instructional Design-The ADDIE Approach. New York: Springer.

Clem, A. L., Hirvonen, R., Aunola, K., \& Kiuru, N. (2021). Reciprocal relations between adolescents' self-concepts of ability and achievement emotions in mathematics and literacy. Contemporary Educational Psychology, 65, 101964. https://doi.org/10.1016/j.cedpsych.2021.101964 
Dominikus, W. Sabon. (2019). Pembelajaran Matematika Berbasis Etnomatematika (PMBE). Makalah disajikan dalam Seminar Nasional Pendidikan Matematika, Universitas Nusa Cendana, Kupang, 21 Juni

Hardiarti, Sylviyani. (2017). Etnomatematika: Aplikasi Bangun Datar Segiempat pada Candi Muaro Jambi. https://media.neliti.com/media/publications/217393-none.pdf

Mullis, V. S., et al. (2015). TIMSS 2015 International Results in Mathematics. Boston: TIMSS \& PIRLS International Study Center

OECD. (2018). PISA 2021 Mathematics Framework (Draft).

OECD. (2019). PISA 2018 Results Combined Executive Summaries. Paris

Suherman, E. (2012). Belajar dan Pembelajaran Matematika. Bandung: Universitas Pendidikan Indonesia.

Sumirattana, S., Makanong, A., Thipkong, S. 2017. Using Realistic Mathematics Education and The DAPIC Problem-Solving Process to Enhance Secondary School Students' Mathematical Literacy. Kasetsart Journal of Social Sciences, Volume 38: 307-315.

Y1lmazer, G., \& Masal, M. (2014). The Relationship between Secondary School Students' Arithmetic Performance and their Mathematical Literacy. Procedia - Social and Behavioral Sciences, 152, 619-623. https://doi.org/10.1016/j.sbspro.2014.09.253

\section{Profil Penulis:}

Nurdin Arifin, merupakan staf pengajar di Universitas
Widya Gama Mahakam Samarinda pada program studi
Pendidikan Guru Sekolah Dasar dengan bidang keahlian
geometri, aljabar, dan statistika pendidikan. Penelitian
penulis lebih fokus pada bidang pendidikan matematika
sekolah dasar. Email: nurdin.arifin91@gmail.com

